\title{
Factors Influencing Indonesian Customer Satisfaction and Customer Loyalty in Local Fast-Food Restaurant
}

\author{
Anas Hidayat ${ }^{1}$, Aprilia P. Adanti ${ }^{1}$, Arief Darmawan ${ }^{1} \&$ Alldila N. A. Setyaning ${ }^{2}$ \\ ${ }^{1}$ Management Department, Universitas Islam Indonesia, Yogyakarta, Indonesia \\ ${ }^{2}$ Master in Management, Universitas Gadjah Mada,Yogyakarta, Indonesia \\ Correspondence: Anas Hidayat, Management Department, Universitas Islam Indonesia, Yogyakarta, Indonesia. \\ E-mail: 883110102@uii.ac.id
}

Received: July 25, 2019 Accepted: August 14, $2019 \quad$ Online Published: August 26, 2019

doi:10.5539/ijms.v11n3p131 URL: https://doi.org/10.5539/ijms.v11n3p131

\begin{abstract}
This paper aims to analyze the influence of customer satisfaction and customer loyalty toward the local fast food restaurant in Indonesia. The variables involved in this study were perceived service quality, perceived product quality, perceived price fairness, customer satisfaction, and customer loyalty. Samples of this study were customers of the local fast food restaurant in Yogyakarta. Quantitative method is used to analyze the relationships within variables. This research examined 200 respondents by spreading the online questionnaires that were analyzed by using Structural Equation Model method. To collect the data, this study used convenience sampling method. The results show that perceived service quality, perceived product quality, and perceived price fairness had a positive and significant influence on customer satisfaction. Also, perceived service quality, perceived product quality, and perceived price fairness had a positive and significant influence on customer loyalty. Finally, customer satisfaction has a positive and significant influence on customer loyalty. Perceived price fairness was the highest influence on Indonesian consumers for being loyal to the local fast food restaurants.
\end{abstract}

Keywords: customer loyalty, customer satisfaction, perceived price fairness, perceived product quality, perceived service quality

\section{Introduction}

Indonesia is the largest market for the Food Service Industry in the ASEAN countries (Agriculture and Agri-Food Canada, 2016). According to AAFC (2016), fast food is one of the top three growth drivers for foodservice market in Indonesia. This study mentioned that the fast food stores in Indonesia continued to rise by $30 \%$ in value sales in 2014. International brands dominated the Indonesian market, such as KFC, McDonald's, Dunkin's Donuts and Burger King. These leading fast food brands show a very tight competition among each other's. To attract consumers' attention, these brands are offering more innovation into their products and services. This condition leads the businessmen to maximize their restaurants' performances to compete in the market. To overcome this, the restaurants need to improve the quality of products, quality service, and set the competitive pricing.

Since the competition in this industry is very tight, companies need to know how to get customers and make them repurchase the products/services. In order to build customer satisfaction and customer loyalty, companies have to understand the needs, wants, and demands of its customers (Adi, Agustin, \& Yoestini, 2012). Customer loyalty is considered as one of the important factors to improve profitability and maintain the position of an organization. Hasan, Ilias, Rahman and Razak (2008) defined loyal customer as a person who buy certain products or brands regularly and repeatedly. A loyal customer is not only willing to buy goods that have been consumed repeatedly, but also willing to recommend it to others in the future. According to Aryani and Rosinta (2010), customer satisfaction is a key to create customer loyalty.

Meanwhile, to create customer satisfaction, business people must pay attention to the service and product quality. According to Putro, Samuel, and Karina (2014), they specified that the quality of service is an effort to comply the needs and desires of consumers and the accuracy of delivery in the balance of consumer expectations. Afterward, customer ratings of service quality are produced based on a comparison between expectations and the 
reality of the services it receives (Japrianto, 2007; Lu, Berchoux, Marek, \& Chen, 2015).

The quality of the product is the features and characteristics of goods or services that can fulfill the needs based on the assessment of suitability with the standards measurement set. In other words, the higher the standards established, the higher the product is rated. If customers are satisfied with a product, they will rebuy it in the future.

Besides, on product quality and service quality, the price factor is also considered as one of the determinant variables to create consumer satisfaction. However, price plays an important role in communicating the quality of goods and services. At a certain price level, if perceived consumer benefits increase, the value obtained by consumers will increase as well. As explained by Malik, Ghafoor, and Iqbal (2012), price fairness is still one of the important rules to create customer satisfaction and purchasing retention. Moreover, customers who are satisfied with the product or company tend to rarely bid for each purchase. Consumers will feel more satisfied if they meet expectations. To create customer satisfaction, the company must be able to sell goods or services with the best quality and pricing following what is obtained. Customer satisfaction creates loyalty to the brands. Usually, the customer will repurchase it in the future.

Consuming fast food product has become a culture for some people, especially for young people (Bugge, 2011). Therefore, it can be an opportunity for local businesses to enter the fast-food industry. There are already big players of fast food restaurant in Indonesia, such as KFC (Kentucky Fried Chicken), McDonald's, Wendy's, etc. Those can be a challenge for local fast food restaurant, especially in Yogyakarta, such as Dirty Chicks, Olive Fried Chicken, Popeye Fried Chicken, etc. The abundance of business competition in the culinary field requires business people to behave creatively, innovatively, and always give more value to every product offered. This research adopts from previous research of Bei and Chiao (2001). The research focused on the antecedents of satisfaction and loyalty of automobile maintenance service. With this conceptualization, this study would like to find out the answer of these questions:

- Does service quality positively influence customer satisfaction?

- Does product quality positively influence customer satisfaction?

- Does price fairness positively influence customer satisfaction?

- Does service quality positively influence customer loyalty?

- Does product quality positively influence customer loyalty?

- Does price fairness positively influence customer loyalty?

The research objective is to examine the effect of service quality, product quality, price fairness on customer satisfaction and loyalty of local fast food restaurant in Yogyakarta. Thus, local fast food business owner can implement an optimal business strategy to create customer loyalty.

\section{Literature Review}

\subsection{Customer Loyalty}

Putro et al. (2014) believed that when someone already has a loyal attitude, he will have a positive view on a brand, have a commitment to the brand, and will repurchase it in the future.

Customer loyalty is very important for good company services and goods to increase profits because when consumers are not loyal to a product that has been issued by a company, it is certain that consumers will turn to other products. Providing the best service, with the aim of customers will return to conduct transactions, can be done with maintaining customer loyalty.

The research that had been conducted by Yuen, and Chan (2010); and Riswandi (2014) found that significant influence between service quality and product quality on satisfaction will create consumer loyalty. Other research is also expressed by Utami and Oetomo (2015) which explained that the quality of service, product quality, price, and customer satisfaction have a significant effect on loyalty.

\subsection{Perceived Service Quality}

Bei and Chiao (2001) assumed that the method for measuring service quality and customer satisfaction is essentially the same, both based on a comparison of expectations and performance. Cronin Jr. and Taylor (1992) found that the quality of service becomes the most important thing in consumer satisfaction. The result of this research is the quality of service that influences consumer satisfaction.

In the research that has been done by Mosahab and Muhammad (2010), the concept that was often used as a tool 
to test the quality of services is called SERVQUAL. This concept was proposed firstly by Parasuraman. Initially, this concept has 10 dimensions but now it has been more simplified into 5 dimensions that are: tangible (physical evidence), empathy, reliability, responsiveness, and assurance.

Another study was done by Adi et al. (2012). He defined service quality as a customer's assessment of the superiority or privilege of a product or service as a whole. The quality of this service is closely related to the customer's perception of the quality of a business. If the perceived service is as expected, the quality of service can be well perceived and satisfactory. Thus, the quality of service depends on the ability of service providers to meet customer expectations consistently (Lu, Berchoux, Marek, \& Chen, 2015).

Based on the above definitions, the quality of service can be interpreted as any form of activities undertaken by companies to meet consumer expectations. Another study on the quality of service with satisfaction is also done by Al Tit (2015). He explained that the quality of service has a positive and significant impact on customer satisfaction. Thus, the proposed hypothesis is as follows:

\section{Hypothesis 1: Perceived service quality has a positive and significant influence on customer satisfaction.}

In this research, the quality of goods, price, and quality of service have an important role to build customer loyalty. The research conducted by Savaranakumar (2014) also indicated that the improvement of service quality can influence the level of customer satisfaction, and customer satisfaction can help increase customer loyalty, empathy, guarantee, and reliability which all of them have a positive effect.

Hasan et al. (2013) defined that service quality affects loyalty. Quality of service becomes the main factor to create customer satisfaction and loyalty. It means that the better the quality of service provided, the higher the consumer loyalty. Thus, the proposed hypothesis is as follows:

Hypothesis 2: Perceived service quality has a positive and significant influence on customer loyalty.

\subsection{Perceived Product Quality}

According to Utami and Oetomo (2015), consumers buy goods or services as a tool to satisfy their needs and desires. However, consumers buy a product not solely because of the physical state of the product but because of the benefits contained in the product purchased.

Furthermore, one of the characteristics that need to be considered about the product is the quality of the product. Product quality has a very close connection with customer satisfaction because the quality of the product can be judged from the ability of the product to create customer satisfaction. To create customer satisfaction, it can be done through the improvement of product quality (Jahanshahi, Gashti, Mirdamadi, Nawaser, \& Khaksar, 2011). With a high level of acceptance of perceived product quality, it will provide a sense of satisfaction to consumers because the company is considered to realize consumer expectations. Thus, the proposed hypothesis is as follows:

Hypothesis 3: Perceived product quality has a positive and significant influence on customer satisfaction.

Besides, to influence customer satisfaction, perceived product quality also affects customer loyalty. A study was conducted by Bei and Chiao (2001) at a gas station that uses a customer satisfaction model to examine the effect of product and service quality on customer satisfaction and loyalty. Their results show that consumers' perceptions of gasoline quality at pump stations are not only positive for customer satisfaction but also directly affect consumer buying behaviour in the future. Nevertheless, perceived product quality has a stronger impact on customer loyalty than satisfaction.

Another statement that was also made by Kassim, Igau, Harun, and Tahajudin (2014) explained that when the perceived quality of a product increases, customer satisfaction is also expected to increase which will ultimately shape brand loyalty. The research is in line with the research conducted by Asmayadi and Hartini (2015). They stated that product quality has a significant influence on customer loyalty. Thus, the proposed hypothesis is as follows:

Hypothesis 4: Perceived product quality has a positive and significant influence on customer loyalty.

\subsection{Perceived Price Fairness}

Another factor to produce consumer satisfaction is price. From the price offered, consumers can assess the quality of services provided. When viewed from the cognitive concept of consumers, the price itself is considered as a sacrifice on something that must be given to get a certain type of product or service. While the price definition according to Kotler and Keller (2012) is a sum of money that can be exchanged for products or services, or exchanged for some benefits from these products and services. The price of service can have a 
significant influence on the perception of quality and satisfaction (Malik, Ghafoor, \& Iqbal, 2012).

When viewed from the cognitive aspect, this definition suggested that assessment of the fairness of prices involves comparisons among price procedures and related standards, references, or norms. Fairness itself is defined as an assessment of whether the process for achieving an outcome is acceptable or not. Price fairness can affect consumer attitudes and behavior. When consumers feel incompatible with the price offered or the price is not feasible, it can cause negative behavior.

When customers pay reasonable, they feel more satisfied. He explained that pricing is an important factor to retain customers and lead to customer satisfaction, which helps increase the profits of all businesses (Malik, Ghafoor, \& Iqbal, 2012).

Other research on price fairness toward satisfaction was also done by Andaleeb and Conway (2006). They explained that price can affect customer satisfaction. Thus, the proposed hypothesis is as follows:

Hypothesis 5: Perceived price fairness has a positive and significant influence on customer satisfaction.

Once customers are confident that they will get the best quality of their products or services, in the long term they will tend to be loyal to the product or service. Research conducted by Al-Msallam and Alhaddad (2016) showed that the hospitality industry found a positive relationship between price and customer loyalty.

Another research on the influence of price fairness to customer loyalty was also done by Bei and Chiao (2001). They explained that to product quality that has a strong influence on consumer loyalty, the reasonable price also has a direct influence on consumer loyalty.

But if consumers feel that the amount of money they have given or sacrificed to get a product or service does not provide benefits, in the future they may not repurchase. Thus, the proposed hypothesis is as follows:

Hypothesis 6: Perceived price fairness has a positive and significant influence on customer loyalty.

\subsection{Customer Satisfaction}

After consumers buy a product or service, consumers will evaluate the product or service whether it is under their expectations or not. If the product or service is following the expectations of consumers, they will feel satisfied and vice versa. This indicated a close relationship between customer satisfaction and evaluation results after consumers make a purchase (Putro et al. 2014).

Satisfaction itself is the level of a person's feelings that arise after comparing the performance of products received with expectations (Kotler \& Keller, 2012). The main factor for customer satisfaction is not the distance between "product performance" and "expectation" or initial expectations. But the main factor is the performance of the production. Satisfaction occur when consumers make certain purchases and then compare the performance and the results they feel and expectations.

Customer satisfaction has the function of service quality, product quality, and price. All these things are measured from the overall consumer ratings (Bei \& Chiao, 2001). Research conducted by Kurniasih (2012) was related to satisfaction and loyalty that reveal customer satisfaction was important for the service provider. When customers feel satisfied, they will disseminate their satisfaction to other prospective customers. Besides, customer satisfaction can increase customer loyalty in a company. For customers who are satisfied with the products or services offered by the company, they are likely to repurchase, which is an indicator of the creation of customer loyalty. Thus, the proposed hypothesis is as follows:

\section{Hypothesis 7: Customer satisfaction has a positive and significant influence on customer loyalty.}

\section{Method}

This research was based on hypothesis testing called the causal research and survey based on data collection. The population of this study was all consumers in Yogyakarta who have visited and bought food at Local Restaurant of Indonesian Fast Food. Sampling method was done by convenience sampling. The number of samples in this study amounted to 200 that met the multivariate test rule of 25 times the number of independent variables.

The data used primary data source obtained from the dissemination of research instruments or questionnaires. Instruments were adapted from Bei and Chiao (2001) and measured by Likert scale 5, where the value starts from the number $1=$ strongly disagree to number $5=$ strongly agree

In this study, there are three demographic charecteristics, namely gender, age, and monthly income. 
Table 1. Respondents' demographic profile

\begin{tabular}{lll}
\hline Demographic Profile & Number of Respondents $(\mathrm{N}=200)$ & Valid percentage (\%) \\
\hline Gender & & \\
Male & 87 & 43.5 \\
Female & 113 & 56.5 \\
Age & & \\
$<$ 20 years & 30 & 15 \\
21-30 years & 170 & 85 \\
31-40 years & 0 & 0 \\
Monthly Income & & \\
$<$ Rp 1,000,000 & 47 & 23.5 \\
Rp 1,100,000-Rp 2,000,000 & 124 & 62 \\
Rp 2,100,000-Rp 4.000.000 & 19 & 9.5 \\
$>$ Rp 4,000,000 & 10 & 5 \\
\hline
\end{tabular}

\subsection{Validity and Reliability of Research Instruments}

Testing the validity of the instrument was done by using the validity of the construct, which measured the validity done by doing a correlation between the score questions and the total score of the construct or variable. The significance test was done by comparing the $r$-value of $r$ with the $r$ table for the degree of freedom $(d f)=n-2$. In this case, $n$ is the number of samples. Question items are said to be valid when $r$ count $>r$ table (Ghozali, 2011). Testing the validity of the research instrument by using the validity of the construct showed all valid items. Instrument reliability testing was done by One-Shot or one measurement only. The tool to test reliability was Cronbach Alpha $(\alpha)$. A construct is said to be reliable if it gives Cronbach Alpha value $>0.60$ (Ghozali, 2011).

Table 2. The result of measurement model

\begin{tabular}{lllllll}
\hline Construct & Items & $(\lambda)$ & $(\varepsilon)$ & t-value & C. R. & Details \\
\hline Service Quality & & & & & 0.955 & Reliable \\
& SQ1 & 0.660 & 0.167 & & & Valid \\
& SQ2 & 0.785 & 0.133 & 9.345 & & Valid \\
& SQ3 & 0.877 & 0.067 & 10.917 & & Valid \\
& SQ4 & 0.857 & 0.096 & 10.236 & & Valid \\
& SQ5 & 0.659 & 0.233 & 7.825 & & Valid \\
Product Quality & & & & & 0.853 & Reliable \\
& PQ1 & 0.703 & 0.300 & 8.711 & & Valid \\
& PQ2 & 0.613 & 0.516 & 7.307 & & Valid \\
& PQ3 & 0.826 & 0.165 & 8.933 & & Valid \\
& PQ4 & 0.660 & 0.369 & & & Valid \\
Price Fairness & & & & & 0.847 & Reliable \\
& PF1 & 0.761 & 0.357 & & & Valid \\
& PF2 & 0.741 & 0.248 & 8.978 & & Valid \\
& PF3 & 0.709 & 0.279 & 8.337 & & Valid \\
Customer Satisafction & & & & & 0.927 & Reliable \\
& CS1 & 0.822 & 0.135 & & & Valid \\
& CS2 & 0.874 & 0.102 & 13.075 & & Valid \\
& CS3 & 0.720 & 0.266 & 11.459 & & Reliable \\
& & & & & 0.886 & Valid \\
Customer Loyalty & Loyalty1 & 0.690 & 0.238 & & & Valid \\
& Loyalty2 & 0.880 & 0.102 & 10.441 & & Valid \\
\hline & Loyalty3 & 0.628 & 0.315 & 9.517 & &
\end{tabular}

\section{Analysis and Results}

The results of model suitability test using chi-square, CMIN/DF, GFI, AGFI, RMSEA, TLI, and CFI indicated that the overall research model was appropriate. The fit indices of the research model shown in Figure 1 are acceptable $\left(\mathrm{x}^{2} / \mathrm{df}=142.467, \mathrm{p}=0.070, \mathrm{RSMEA}=0.031, \mathrm{GFI}=0.929, \mathrm{CMIN} / \mathrm{DF}=0.119, \mathrm{AGFI}=0.899, \mathrm{TLI}=\right.$ 0.983 , CFI $=0.987$ ). Overall Chi-Square value with the probability of $0.070>0.05$ showed overall fit model (Overall goodness of fit). The recommended level of acceptance was significance when $p>0.05$ or $p>0.10$. 
Also, after the compatibility of RMSEA, TLI, and GFI values were tested and compared to the reference value (cut of value), equations of structural model results were good except AGFI which was still below the criteria value but it can be generally tolerated. Schematically the path analysis results are shown in Figure 1 below:

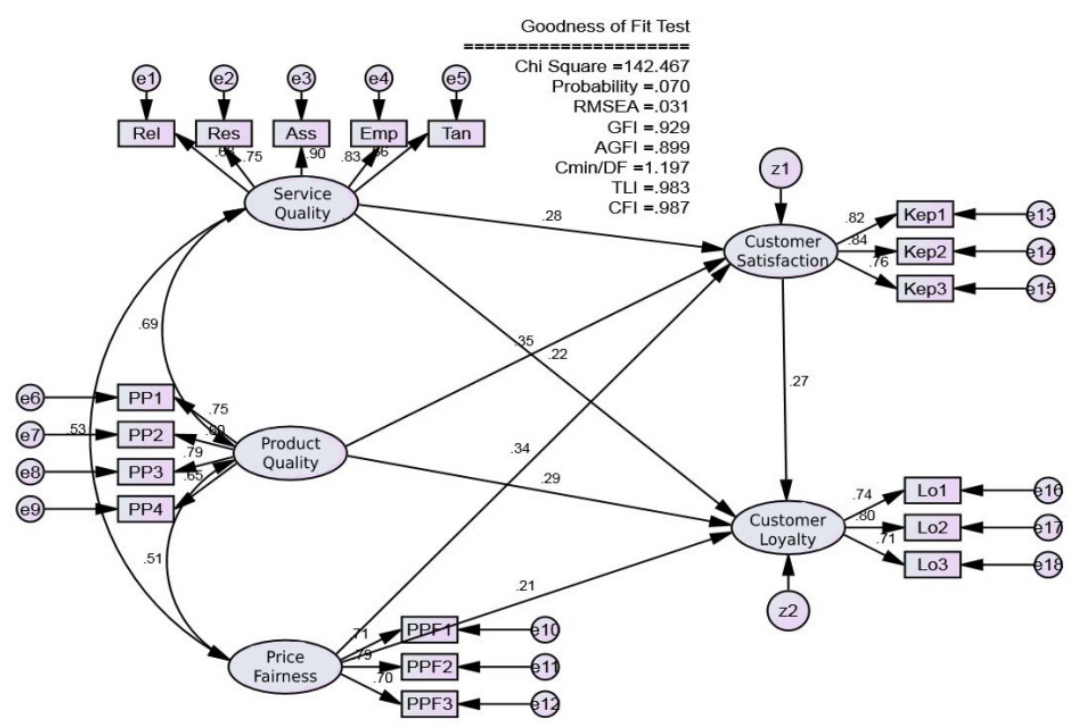

Figure 1. Structural model

Table 3. Evaluation of weight regression test of causality

\begin{tabular}{llllll}
\hline Variable & Estimation & S.E. & C.R. & P & Decision \\
\hline Service Quality $\rightarrow$ Customer Satisfaction & 0.284 & 0.136 & 2.991 & 0.003 & Supported \\
Service Quality $\rightarrow$ Customer Loyalty & 0.219 & 0.139 & 2.134 & 0.033 & Supported \\
Product Quality $\rightarrow$ Customer Satisfaction & 0.353 & 0.099 & 3.553 & 0.000 & Supported \\
Product Quality $\rightarrow$ Customer Loyalty & 0.285 & 0.111 & 2.428 & 0.015 & Supported \\
Customer Satisfaction $\rightarrow$ Price Fairness & 0.343 & 0.068 & 4.128 & 0.000 & Supported \\
Price Fairness $\rightarrow$ Customer Loyalty & 0.206 & 0.075 & 2.113 & 0.035 & Supported \\
Customer Satisfaction $\rightarrow$ Customer Loyalty & 0.271 & 0.127 & 2.021 & 0.043 & Supported \\
\hline
\end{tabular}

The result of regression among variables often referred to as loading factor or lambda value estimation which can be used to analyze the variable causality test. It was on the significance of CR (Critical Ratio) value with the probability $(\mathrm{p})=0.05$.

Further explanation of regression weight evaluation analysis can describe and explain test of hypotheses as follows, service quality variable had a significant influence on satisfaction with the significant level of equal to 0.003 which was less than the probability value of 0.05 . It means hypothesis 1 was accepted. Service quality variable had a significant influence on loyalty with the significant level of equal to 0.033 which was less than the probability value of 0.05 . It means hypothesis 2 was accepted. Product quality variables had a significant influence on satisfaction with the significant level of 0.000 which was smaller than the probability value of 0.05 . It means hypothesis 3 was accepted. Product quality variables had a significant influence on loyalty with the significance level of 0.015 which was smaller than the probability value of 0.05 . It means hypothesis 4 was accepted. The price fairness variable had a significant influence on satisfaction with the significance level of 0.000 which was smaller than the probability value of 0.05 . It means hypothesis 5 was accepted. Price reasonableness variable had a significant influence on loyalty with the significance level of equal to 0.035 which was less than the probability value of 0.05 . It means hypothesis 6 was accepted. The satisfaction variable had a significant influence on loyalty with the significance level of 0.043 which was less than the probability value of 0.05 . It means hypothesis 7 was accepted.

\section{Discussion}

The findings in the testing of hypotheses 1 and 2 were consistent with Bei and Chiao (2001) who found that better quality of service would increase customer satisfaction and loyalty. Service quality was a measure of how 
good the level of service which was provided with customer expectations. This is also consistent with Al Tit (2015) which explains that service quality has a positive and significant impact on customer satisfaction. Quality of service is an absolute thing that must be owned by the company or institution offered services because of its quality of services provided to consumers, companies or agencies can measure the level of performance that has been achieved. In line with Saravanakumar (2014), he also stated that the improvement of service quality can influence the level of customer satisfaction, and customer satisfaction can help increase customer loyalty, empathy, guarantee, and reliability which all of them have positive effect. Quality of service provided by the company would cause consumer perception. The greater the perception of the quality of service received, the greater the expectations of consumers fulfilled and the greater the customer satisfaction.

With improved service quality, it can lead to customer loyalty and tend to attract new customers. Consumers who are loyal to service products can also mean that consumers are satisfied with the need to buy more than one and will continue to visit local Fast Food Restaurants. The statement was supported by research conducted by Al Msalam (2014) which showed a positive relationship between service quality and customer loyalty. It means that high service quality will result in customer satisfaction and loyalty, a strong desire to recruit others, reduce complaints and improve customer retention rates. In line with Hasan et al. (2013), they show that service quality affects loyalty. Quality of service becomes the main factor to create customer satisfaction and loyalty, meaning that the better the quality of service provided, the higher the consumer loyalty.

The findings of hypotheses 3 and 4 were also consistent with Bei and Chiao (2001) and Bowen and Chen (2001) who found that better product quality will increase customer satisfaction and loyalty. Product quality is an important thing for every company should do if they want their products to compete in the market to meet the needs and wants of consumers. Constant with Jahanshahi, Gashti, Mirdamadi, Nawaser and Khaksar (2011), customer satisfaction can be achieved through improvement of product quality. Products can satisfy consumers when assessed meet or exceed the wishes and expectations. When purchasing a product made by consumers, it can meet the needs and in accordance with consumer expectations; thus, it will create customer satisfaction. On the other hand, consumers will feel extremely satisfied if the received product performance exceeds expectations. Opinions about the effect of product quality on satisfaction are presented by Putro et al. (2014). They explained that product quality has a significant effect on consumer satisfaction. Product quality was also a crucial thing to create customer satisfaction and customer loyalty. Kassim, Igau, Harun and Tahajudin (2014) explained that when perceived quality of a product increases, customer satisfaction is also expected to improve that will ultimately shape brand loyalty. If the consumer is satisfied with the product purchased, the consumer will get the loyalty of the purchase. Thus, the buyer will repurchase in the future. In addition, satisfied customers will also recommend the product to others. This is another form of customer loyalty. Next, the study conducted by Sembiring et al. (2014) in the McDonald's fast food restaurant shows that product quality has a direct and significant effect on customer loyalty. The explanation of this research was the quality of the product was an important part and is needed to get serious attention. Thus, every company persists and become the choice of customers in restaurant business.

The findings of hypotheses 5 and 6 were consistent with Bei and Chiao (2001). The research found that the reasonableness of the price had positive and significant influence on customer satisfaction and loyalty. This means that a more acceptable predetermined price will increase customer satisfaction and loyalty. In line with Malik, Ghafoor and Iqbal (2012), the price of service can have significant influence on the perception of quality and satisfaction. To create customer satisfaction, the company does not only take into consideration the quality of the product and the quality of the service to be offered to the prospective customers, but on the other hand the company should consider the price in every product/service it sells. Price became something that was very important for the customer as a guide to measure the suitability between the benefits of products received and the sacrifices that had been given either in the form of money or certain sacrifices. Customers will also give price as one of the perceived standards of satisfaction (Tomida \& Satrio, 2016). Research conducted by Gumussoy and Koseoglu (2016) found that price fairness had a significant influence on customer satisfaction.

Price can indicate the brand quality of a product, where the price set will form the perception on the consumer's mind. From positive thinking, the corresponding price has an appropriate quality that will affect consumer loyalty. Al-Msallam and Alhaddad (2016) showed that the hospitality industry found positive relationship between price and customer loyalty. Comparison of prices can be considered cheap for consumers if consumers can see and receive value greater than the price set. In this case consumers did not want to feel harmed. These results also supported the results of the research of Utami dan Oetomo (2015). It can be concluded that prices had positive influence on consumer loyalty.

The findings in the test of hypothesis 7 were consistent with the results of Bei and Chiao (2001) which explained 
that satisfaction had positive influence on customer loyalty. As customer satisfaction increases, it will increase customer loyalty. This was because consumers who had assumed that consumer expectation had been fulfilled on basic needs such as quality of service, quality of product quality and supported by fairness of competitive price. Hence, consumer loyalty will be stronger. Thus, consumers will increase their visit and willing to inform things or recommend to others (Zeithaml, 2002). The relationship between customer satisfaction and customer loyalty was directly proportional, meaning that when satisfaction increases, loyalty will also increases (Mosahab \& Muhammad, 2010).

\section{References}

Adi, R., Agustin, F., \& Yoestini. (2012). Analisis pengaruh harga, kualitas produk, dan kualitas layanan terhadap kepuasan pelanggan. Diponegoro Business Review, 1(1), 1-9.

Agriculture and Agri-Food Canada. (2016). Food service profile: Indonesia. Retrieved from http://www.agr.gc.ca/resources/prod/Internet-Internet/MISB-DGSIM/ATS-SEA/PDF/6769-eng.pdf

Al-Msallam, S. (2014). The Effects of Customer Expectation and Perceived Service Quality on Customer Satisfaction. International Journal of Business and Management Invention, 3(8), $79-84$.

Al-Msallam, S., \& Alhaddad, A. (2016). Customer satisfaction and loyalty in the hotel industry: The mediating role of relationship marketing (PLS approach). Journal of Research in Business and Management, 4(5), $32-42$.

Al-Tit, A. A. (2015). The effect of service and food quality on customer satisfaction and hence customer retention. Asian Social Science, 11(23), 129-139. https://doi.org/10.5539/ass.v11n23p129

Andaleeb, S. S., \& Conway, C. (2006). Customer satisfaction in the restaurant industry: An examanation of the transaction-spesific model. The Journal of Services Marketing, 20(1), 3-11. https://doi.org/10.1108/08876040610646536

Aryani, D., \& Rosinta, F. (2010). Pengaruh kualitas layanan terhadap kepuasan pelanggan dalam membentuk loyalitas pelanggan. Jurnal Ilmu Administrasi dan Organisasi, 17(2), 114-126.

Asmayadi, E., \& Hartini, S. (2015). The impact of service quality and product quality towards customer loyalty through emotional and functional values in traditional markets in pontianak, indonesia. European Journal of Business and Management, 7(5), 128-135.

Bei, L. T., \& Chiao, Y. C. (2001). An integrated model for the effects of perceived product, perceived service quality, and perceived price fairness on consumer satisfaction and loyalty. Journal of Consumer Satisfaction, Dissatisfaction and Complaining Behavior, 14, 125-141.

Bowen, J. T. B., \& Chen, S. L. (2001). The relationship between customer loyalty and customer satisfaction, International Journal of Contemporary Hospitality Management, 13(5), 213-217. https://doi.org/10.1108/09596110110395893

Bugge, A. B. (2011). Lovin' it? A study of youth and the culture of fast food. Food Culture and Society an International Journal of Multidisciplinary Research, 1(14), 71-89. https://doi.org/10.2752/175174411X12810842291236

Cronin Jr., J. J., \& Taylor, S. (1992). Measuring service quality: a reexamination and extension. The Journal of Marketing, 56, 55-68. https://doi.org/10.1177/002224299205600304

Ghozali, I. (2011). Model Persamaan Struktural Konsep Dan Aplikasi Dengan Program AMOS 21.0 (4th ed.). Semarang: Badan Penerbit UNDIP.

Gumussoy, C. A., \& Koseoglu, B. (2016). The effect of service quality, perceived value and price fairness on hotel customer's satisfaction and loyalty. Journal of Economics, Business and Management, 4(9), 523-526.

Hasan, H. F. A., Ilias, A., Rahman, R. A., \& Razak, M. Z. A. (2008). Service quality and student satisfaction: a case study at private higher education institutions. International Business Research, 1(3), 163-175. https://doi.org/10.5539/ibr.v1n3p163

Jahanshahi, A. A., Gashti, M. A. H., Mirdamadi, S. A., Nawaser, K., \& Khaksar, S. M. S. (2011). Study the effect of customer service and product quality on customer satisfaction and loyalty. International Journal of Humanities and Social Science, 1(7), 253-260.

Japrianto, E. (2007). Analisa kualitas layanan sebagai pengukur loyalitas pelanggan Hotel Majapahit Surabaya dengan pemasaran relasional sebagai variabel interveving. Jurnal Jurusan Manajemen Perhotelan, 3(1), 
34-42. https://doi.org/10.9744/jmp.3.1.34-42

Kasim, A. W. M., Igau, O. A., Harun, A., \& Tahajudin, S. (2014). Mediating effect to customer satisfaction on perceived product quality, perceived value, and their relation to brand loyalty. International Journal of Research in Management \& Business Studies, 1(2), 13-18.

Kurniasih, I. D. (2012). Pengaruh harga dan kualitas pelayanan terhadap loyalitas melalui variabel kepuasan (Studi pada Bengkel Ahass 0002-Astra Motor Siliwangi Semarang). Jurnal Administrasi Bisnis, 1(1), $37-45$.

Lu, C., Berchoux, C., Marek, M. W., \& Chen, B. (2015). Service quality and customer satisfaction: qualitative research implications for luxury hotels. International Journal of Culture, Tourism and Hospitality Research, 9(2), 168-182. https://doi.org/10.1108/IJCTHR-10-2014-0087

Malik, M. E., Ghafoor, M. M., \& Iqbal, H. K. (2012). Impact of brand image, service quality and price on customer satisfaction in Pakistan telecommunication sector. International Journal of Business and Social Science, 3(23), 123-129.

Montung, P., Sepang, J., \& Adare, D. (2015). Pengaruh kualias produk, kualitas layanan dan presepsi harga terhadap kepuasan pelanggan di Restoran Kawan Baru. Jurnal Berkala Ilmiah Efisiensi, 15(5), 678-689.

Mosahab, R., \& Muhammad, O. (2010). Service quality, customer satisfaction and loyalty: A test of mediation. International Business Research, 3(4), 72-80. https://doi.org/10.5539/ibr.v3n4p72

Ngoc, M. K., \& Uyen, T. T. (2015). Factor affecting guest perceived service quality, product quality, and satisfaction: A study luxury restaurant in Ho Chi Minh City, Vietnam. Journal of Advanced Management Science, 3(4), 284-291. https://doi.org/10.12720/joams.3.4.284-291

Putro, S. W., Samuel, H., \& Karina, R. (2014). Pengaruh kualitas layanan dan kualitas produk terhadap kepuasan pelanggan dan loyalitas konsumen Restoran Happy Garden Surabaya. Jurnal Manajemen Pemasaran, 2(1), 1-9. https://doi.org/10.30736/jpim.v1i2.25

Riswandi, I. (2014). Pengaruh kualitas layanan, kualitas produk dan kepuasan nasabah sebagai prediktor dalam meningkatan loyalitas nasabah. Jurnal Organisasi dan Manajemen, 10(2), 179-196.

Saravanakumar, D. (2014). Effect of service quality on customer loyalty: Emprical evidence from co-operative bank. International Journal of Business and Administration Research Review, 2(4), 87-94.

Sembiring, I. J. \& Kusumawati, A. (2014). Pengaruh kualitas produk dan kualitas pelayanan terhadap kepuasan pelanggan dalam membentuk loyalitas pelanggan. Jurnal Administrasi Bisnis, 15(1), 1-10.

Tomida, M., \& Satrio, B. (2016). Pengaruh harga dan citra merek terhadap loyalitas pelanggan produk footwear yongki komaladi. Jurnal Ilmu dan Riset Manajemen, 5(7).

Utami, D., \& Oetomo, W. (2015). Pengaruh kualitas produk, pelayanan, harga dan lokasi terhadap loyalitas dengan kepuasan sebagai variabel intervening. Jurnal Ilmu dan Riset Manajemen, 4(5), 1-19.

Yuen, E. F. T., \& Chan, S. S. L. (2010). The effect of retail service quality and product quality on customer loyalty. Journal of Database Marketing \& Customer Strategy Management, 17(3-4), 222-240. https://doi.org/10.1057/dbm.2010.13

Zeithaml, V. A. (2002). Consumer perception of price, quality, and value: A means-end model and synthesis of evidence. Journal of Marketing, 52, 2-22. https://doi.org/10.1177/002224298805200302

\section{Copyrights}

Copyright for this article is retained by the author, with first publication rights granted to the journal.

This is an open-access article distributed under the terms and conditions of the Creative Commons Attribution license (http://creativecommons.org/licenses/by/4.0/). 